\title{
Varietal description of sorghum phenotypes for registration
}

\section{Caracterización varietal de fenotipos de sorgo con fines de registro}

\author{
AVENDAÑO-LÓPEZ, Adriana Natividad, SANCHEZ-MARTINEZ, Jóse, PADILLA-GARCIA, José \\ Miguel and ARELLANO-RODRIGUEZ, Luis Javier
}

Instituto de Ciencia y Tecnología de Semillas CUCBA Universidad de Guadalajara

ID $1^{\text {st }}$ Author: Adriana Natividad, Avendaño-López / ORC ID: 0000-0003-1713-1165, CVU CONACYT ID: 236981

ID $1^{\text {st }}$ Coauthor José, Sánchez-Martínez / ORC ID: 00000002-1451-1149, CVU CONACYT ID: 63408

ID $2^{\text {nd }}$ Coauthor: José Miguel, Padilla-García / ORC ID: 0000-0002-5627-3986, CVU CONACYT ID: 236981

ID $3^{\text {rd }}$ Coauthor: Luis Javier, Arellano-Rodríguez / ORC ID: 0000-0002-3188-0245, CVU CONACYT ID: 65995

DOI: $10.35429 / J E S N .2019 .16 .5 .1 .4$

Received June 26, 2019; Accepted December 28, 2019

\begin{abstract}
The goal of a plant breeding is the generation of new varieties that become agricultural inputs for farmers. For this, it is necessary to verify the genetic identity of the materials and have the breeder's registration and title. The University of Guadalajara has generated varieties and quality sorghum hybrids that must be released to the public. This work was developed to establish the methodology of varietal characterization, an essential requirement for obtaining a breeder's title before the National Seed Inspection and Certification Service (SNICS). For this, 2 andro-sterile lines (A) and a fertility restoration line $(\mathrm{R})$ were described, in two locations and two production cycles. By establishing according to ranges of variation and stability, the appropriate sample size and differential phenotypic characters that facilitated identification.
\end{abstract}

Sorghum, Genetic identity, Varietal description

\begin{abstract}
Resumen
El objetivo de un programa de mejoramiento genético es la generación de nuevas variedades que lleguen a ser insumo agrícola para los productores. Para ello es necesario comprobar la identidad genética de los materiales y contar con el registro y título de obtentor. La Universidad de Guadalajara, ha generado variedades e híbridos de sorgo de calidad que deben ser liberados al público. El presente trabajo se desarrolló para establecer la metodología de caracterización varietal, requisito indispensable para obtención de título de obtentor ante el Servicio Nacional de Inspección y Certificación de Semillas (SNICS). Para ello se describieron 2 líneas androestériles (A) y una línea restauradora de la fertilidad (R), en dos localidades y dos ciclos de producción. Logrando establecer de acuerdo a rangos de variación y estabilidad, el tamaño de muestra adecuado y los caracteres fenotípicos diferenciales que facilitaron la identificación.
\end{abstract}

Sorgo, Descripción Varietal

Citation: AVENDAÑO-LÓPEZ, Adriana Natividad, SANCHEZ-MARTINEZ, Jóse, PADILLA-GARCIA, José Miguel and ARELLANO-RODRIGUEZ, Luis Javier. Varietal description of sorghum phenotypes for registration. Journal of Environmental Sciences and Natural Resources. 2019, 5-16: 1-4

\footnotetext{
* Correspondence to Author (email: aavedan @ cucba.udg.mx)

$\dagger$ Researcher contributing first author.
} 


\section{Introduction}

In Mexico, sorghum is a crop of great importance, thanks to its adaptability and its nutritional properties. It is so versatile that it adapts to very adverse environmental conditions representing an alternative in the production of grain and fodder.

In the practice of genetic improvement of seeds, either commercially or experimentally, the existence of a varietal description of the phenotypes of materials to be used is indispensable. Since although important technological advances have been implemented in the identification at the molecular level, this type of analysis is used as complementary and does not replace the phenotypic description, either because of its high specialization that in some cases makes its repetitiveness difficult.

In a varietal description, the phenotypic characteristics to which the behavior of a material should be adjusted are explicitly mentioned, and it is useful to make better use of it, with the possibility of exploiting its potential.

Through this document it is possible to legitimize and register a variety before the official agency, in addition to enabling its dissemination and properly performing its multiplication, guaranteeing its varietal purity not only during the production stage, but also to strengthen the credibility of the promotion of new varieties in the market.

CIAT (1983) Notes that for the approval of a new variety, it is a requirement that it be clearly identifiable and distinct, as well as stable and homogeneous. The complete certification process involves the control of the origin of the variety and the supervision during the multiplication and the benefit of it, to avoid mixing with other materials.

According to CIAT (1983), when the varietal description is made in the phenotype observing, the plants of a variety will depend on the genetic potential of each plant and its expression (phenotype), according to the environmental effects present. Therefore, the manifestation of a phenotype should be known to try to differentiate variations due to genetic effects from those that occur due to environmental effects.
The objective of the present work was, in addition to the characterization of the materials, to generate information that allows determining the sample size, that is, the convenient number of plants to be used in the varietal description of qualitative and quantitative phenotypic characteristics to achieve the optimization of resources and time, without sacrificing accuracy. Under the hypothesis that in the development of a varietal description the sample size varies according to the character under study. And increasing the number of plants described, the coefficient of variation decreases and when it presents some stability in its values, the optimal sample size is obtained.

\section{Methodology}

The descriptions will be measured in more than one environment, for this reason the present work was carried out in two locations: The experimental agricultural field of the University Center of Biological and Agricultural Sciences CUCBA of the University of Guadalajara where work has been done in training and release of new varieties and / or sorghum hybrids; Located on the Las Agujas property, Zapopan Latitude: $20^{\circ} 43^{\prime} 12$ " N; Longitude: $103^{\circ} 23^{\prime} 30^{\prime \prime} \mathrm{O}$ Altitude: 1,567 masl. (Figure 1) The second town was Poncitlán. Location: Latitude: $20^{\circ} 18$ '15' 'at $20^{\circ} \quad 26^{\prime} \quad 15 \quad$ " N Longitude: $102^{\circ} 16$ '45' 'Altitude: 1,524 masl. We worked with two androsterile lines and a fertility restorer (parental of commercial hybrids (ATx 626, ATX 399 and R-573). In both cases the crop was managed with the appropriate technological package for each area. The production plots were of an area of $500 \mathrm{~m}$ and the number of plants described per character was 100.

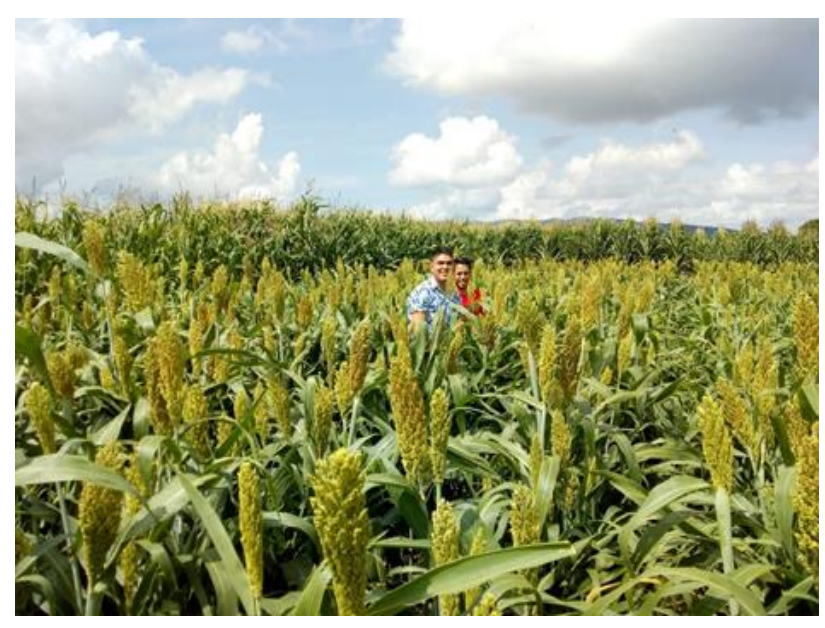

Figure 1 Town Las needles, Zapopan Jal. 
In order to provide elements that facilitate the identity of the materials described, the methodology proposed by UPOV and the International Center for Tropical Agriculture CIAT was used. Varietal purity is the genetic identity of plants, it is important to note that it does not necessarily indicate homozygous or total uniformity among the population, but that the multiplied seed will faithfully reproduce the characteristic phenotype of the variety. (Serrato, 1995). The characters described were:

\begin{tabular}{|l|}
\hline Qualitative in seedling state \\
\hline Anthocyanin staining of the beetle \\
\hline Anthocyanin coloration of the back of the first leaf \\
\hline Anthocyanin coloration in the first leaf sheath \\
\hline Quantitative adult plant \\
\hline Days to anthesis \\
\hline Plant height in panicle emergency \\
\hline Total height at maturity \\
\hline Stem diameter \\
\hline Length of the third sheet from the top \\
\hline Width of the third sheet from the top \\
\hline Visible length of the peduncle ( \\
\hline Weight of one thousand seeds in g \\
\hline Qualitative characters \\
\hline D7 Leaf color green \\
\hline D8 Extension of the discoloration in the central rib. \\
\hline D10 Leaf flag yellow coloration of the central rib \\
\hline Gluma, color in bloom \\
\hline Gluma, anthocyanin coloration in bloom \\
\hline Gluma, anthocyanin staining in pubescence \\
\hline Motto, edge formation. \\
\hline Stigma, anthocyanin staining \\
\hline Stigma, yellow coloring \\
\hline Stigma, length \\
\hline Flower with pedicel flower length \\
\hline Panicle density at the end of flowering \\
\hline Panicle, branch length \\
\hline Panicle, density at maturity. \\
\hline Panicle, mature form \\
\hline Caryopside, color after threshing \\
\hline Dorsal grain view \\
\hline Grain Profile View \\
\hline Grain, germ brand size \\
\hline Grain, surface covered by glume \\
\hline Predominant endosperm texture \\
\hline Grain, color of crystalline albumen \\
\hline
\end{tabular}

Considering that the optimal sample size is one in which the coefficient of variation presents values with a tendency to stabilize, the values of the described characters were analyzed through measures of central tendency and through comparative graphs to make it possible to determine the point closer to stability or balance, resulting in the optimal sample number. Regarding the statistical parameters used in the varietal description, CIAT mentions that when it comes to qualitative characteristics that can be measured based on the mean $(\mu)$ standard deviation $(\sigma)$ coefficient of variation $(\mathrm{CV})$ and range $(\mathrm{R})$
In order to know the degree of precision achieved with the number of plants used as the optimal sample size, the formula proposed by Cochran (1984) was used.

$$
\text { Where: } \mathrm{n}=\frac{\left(\mathrm{t}^{2}\right) \quad\left(\mathrm{s}^{2}\right)}{\mathrm{d}^{2}}
$$

$\mathrm{n}=$ sample size

$\mathrm{t}=$ degree of reliability

$\mathrm{s}^{2}=$ variance

$\mathrm{d}^{2}=$ degree of accuracy desired

\section{Results}

With the values of the mean, range and coefficient of variation, it was possible to estimate the magnitude of variation of the characters, in Figure 2 it is exemplified that from 40 plants the trend of the mean and the coefficient of variation is maintained

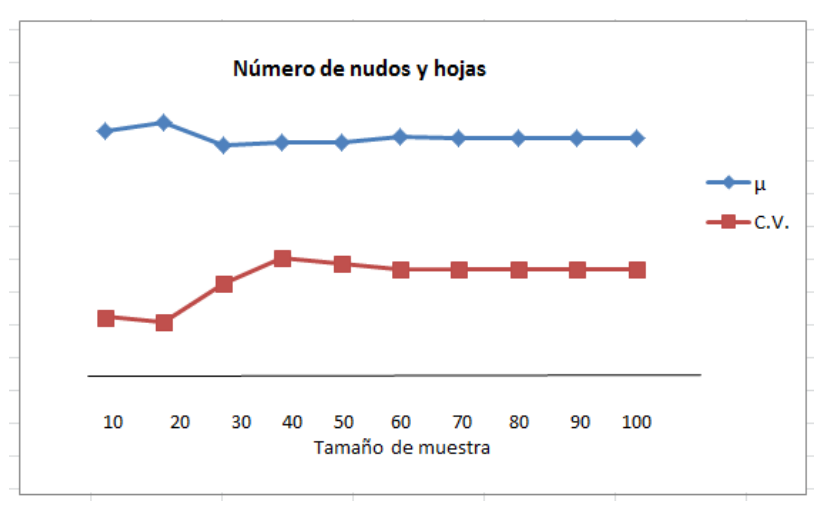

Figure 2 Average behavior and coefficient of variation of the number of knots and leaves

In figure 3 , the average length of the spine is shown for the character from a sample size of 20 plants, the mean is not modified.

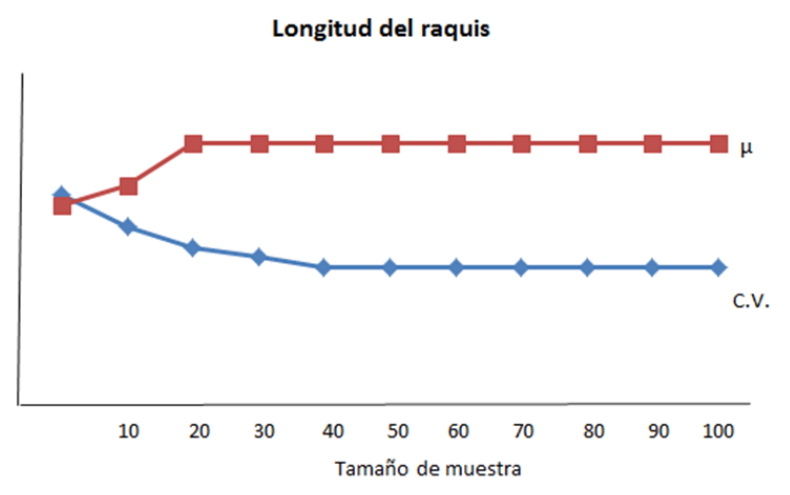

Figure 3 Sample Size Behavior Regarding Averages 
The variation in the qualitative characteristics was more stable even with a smaller sample size, which confirms that the interaction with the environment in this type of characteristics is smaller (Figure 3)

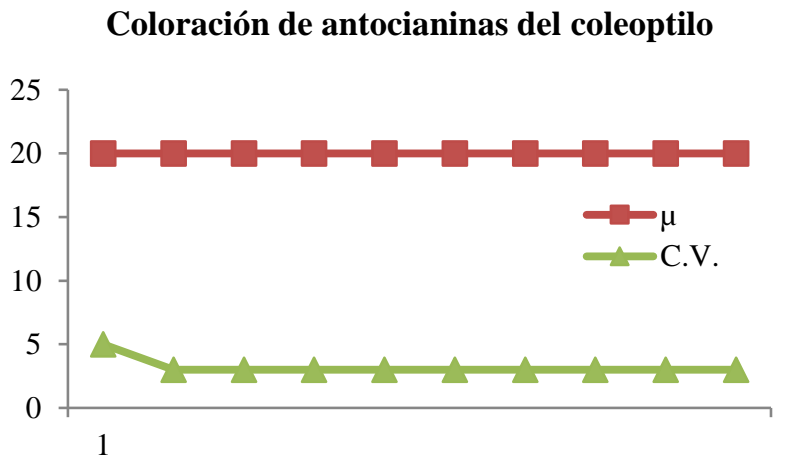

Both qualitative and quantitative characters that offer a greater degree of reliability for presenting less interaction with the environment were:

Quantitative: number of secondary branches. Plant height, rachis length and number of knots and leaves

Qualitative: Predominant color of hypocotyl, predominant color of anthers, glumes and central vein, predominant habit of leaves and predominant type of head or panicle

With greater interaction and less stable: Head width, leaf area, excersion and number of nodes in the spine, considered as not very reliable characters in the identification of materials.

\section{Conclusions}

In the characters described for the 3 lines used, the optimal sample number ranges between 30 and 60

The sample size for qualitative characters was 7 with a degree of accuracy of $99 \%$

\section{References}

CIAT. 1987. Producción de semilla genética y básica. Responsabilidad de un programa de mejoramiento. Memorias del curso avanzado sobre producción de semilla básica del 27 de Abril al 29 de Mayo. Cali Colombia.
CIAT (Centro Internacional de Agricultura Tropical), 1983. Metodologías para obtener semillas de calidad arroz, frijol, maíz, sorgo. Ed. Unidad de semillas CIAT. Cali, Colombia. $198 \mathrm{p}$.

SNICS. 2002. Guía técnica para la descripción varietal para sorgo (Sorgum bicolor L.). México $15 \mathrm{p}$.

UPOV (International Union for the Protection of New Varieties of Plants). 2000. List of TGP documents and latest issue dates (TC/36/8). Technical committee. April 3 to 5 ThirthySixthy Session. Geneva, Swiss 